\title{
Mevlânâ Zafer Ali Hân'ın Özgürlük Mücadelesi ve Hapishane Günleri
}

\section{Zafar Ali Khan's Struggle for Freedom and His Prison Days}

\author{
Muhsin Ramazan IŞSEVER ${ }^{1}$ []
}

'Sorumlu yazar/Corresponding author: Muhsin Ramazan IŞSEVER (Doktora Öğrencisi), İstanbul Üniversitesi, Sosyal Bilimler Enstitüsü, Doğu Dilleri ve Edebiyatları Anabilim Dalı, Urdu Dili ve Edebiyatı Bilim Dalı, İstanbul, Türkiye E-posta: muhsin.issever@istanbul.edu.tr ORCID: 0000-0001-7979-5827

Başvuru/Submitted: 05.12.2019

Revizyon Talebi/Revision Requested: 05.12.2019

Son Revizyon/Last Revision Received: 17.12.2019

Kabul/Accepted: 17.12.2019

Atıf/Citation: Issever, Muhsin Ramazan. "Mevlânâ Zafer Ali Hân'ın Özgürlük Mücadelesi ve Hapishane Günleri." Şarkiyat Mecmuası Journal of Oriental Studies 35 (2019), 11-22. https://doi.org/10.26650/jos.2019.008

\section{ÖZ}

Mevlana Zafer Ali Hân, Hindistan Pakistan alt kıtasının İngilizlere karşı yürüttüğü özgürlük mücadelesinde fikrî, edebî ve siyasî kişiliğiyle ön saflarda yer almış çok yönlü bir kişiliktir. Zulüm ve baskılara karşı gazeteci kimliğiyle mücadele etmiştir. İngiltere'ye giderek Hint alt kıtasındaki baskıcı basın kanunları eleştirmiş ve özgür basının Hint alt kıtasında oluşması için sesini duyurmaya çalışmıştır. Bu cesaret ve açık sözlülükle mücadelesinden dolayı birçok kez hapsedilmiş, gazetesi kapatılmış ve kefalet ödenerek tekrar açılmıştır. Beş seneden fazla hapiste hayatını geçirmiştir. Kendi ve ailesinin servetini Hint alt kıtası Müslümanlarının seslerini duyurmak için seferber etmiştir. Malî zorluklara sabretmiş, hapishane eziyetlerine katlanmış ancak özgürlük mücadelesini ve Türklere yardımdan geri durmamıştır. Müslüman Hint halkının özgür olarak ayrı bir devlet olarak yaşamasında rol almıştır.

Anahtar kelimeler: Mevlana Zafer Ali Hân, Özgürlük Mücadelesi, Hint alt kıtası, Osmanlı Devleti, Zemindar Gazetesi

\section{ABSTRACT}

Mavlana Zafar Ali Khan was a multi-faceted figure who rose to prominence with his intellectual, literary and political personality during the struggle against the British for the freedom of the Indian subcontinent. As a journalist he fought against the persecution and oppression of the English Rulers of that land, even going to England to criticize the repressive press laws on the Indian subcontinent and trying to make his voice heard for the formation of a free press there. He was imprisoned many times for his courage and frankness and his newspaper was closed and reopened upon payment of bail. . Despite spending more than five years in prison, he mobilized his own wealth and that of his family's to make the voices of the Muslims of the Indian subcontinent heard. He faced financial difficulties and endured prison torture, but did not stop the struggle for freedom and aid to the Turks. He played a big role in the freedom of the Indian Muslim people and in their establishment as a separate state.

Keywords: Mavlana Zafar Ali Khan, Freedom Struggle, Indian Sub-continent, Ottoman Empire, Zamindar Newspaper 


\section{EXTENDED ABSTRACT}

Mavlana Zafar Ali Khan is one of the most important personalities of the Indian subcontinent. He supported the struggle for freedom on the subcontinent against British rule. Zafar Ali Khan started to determine the political agenda of the subcontinent and guided subcontinent politics. Mavlana Zafar Ali Khan became a main player in the struggle for freedom against the British, and using the Zamindar newspaper he especially supported the struggle for freedom in the field of journalism. He was called the "Father of Indian Journalism" because he was the first person on the Indian subcontinent to start to defend Indian local people, especially Indian Muslims' rights through journalism and through his speeches. Moreover, he tried to educate people and, by means of journalism, get them to unite and to support the Ottoman Islamic Caliphate which was the last independent country for Muslims. Zafar Ali Khan's dream was to establish an Islamic Union, and in order to do this he continued his struggle for the Islamic Union with his writings which strengthened the Ottoman Islamic Caliphate and showed a reaction against the British in a period when the Ottoman Empire was collapsing and when the Indian subcontinent was a colony under the British. In this way the people of the Indian subcontinent enthusiastically began to struggle for their rights. In particular, he wrote about Tripoli, the Balkan wars, and the Turkish National Struggle in the "Crescent and the Cross of the war" and also wrote many articles in this direction. In this way, while standing by the Turks on the one hand, and by shaping national consciousness on the subcontinent on the other, he created public opinion in the struggle for freedom against the British. The Hindu people also took their place among the pioneers of the Khilafat Movement. In particular, he was closely followed by the British with his fiery speeches and his articles. The British tried to close his newspaper down many times through various processes and after each closure which incurred a penalty, he paid this with the support of the Indian people and continued on his path of freedom. He was also sentenced to prison many times. During his imprisonment, he continued to write political poems and kept up his struggle for freedom as well. Mavlana Zafar Ali Khan's name is even today counted as a national symbol of the Indian Subcontinent. His intellectuality, bravery and confidence are accepted by everyone. 


\section{Giriş}

Hint basınının babası unvanına sahip Mevlânâ Zafer Ali Hân¹ (1874-1950) Hint alt kıtası özgürlük hareketinin öncü isimlerindendir. Farsça, Arapça, İngilizce dillerinde tercümanlık yapmış, hitabeti ve kalemi güçlü bir şairdir. İngilizlere karşı başlatılan özgürlük mücadelesini siyasî içerikli yüzlerce şiirleriyle desteklemiştir. 18 Ocak 1874 tarihinde Hint alt kıtasındaki Pencap eyaletinin Siyalkot şehrinin Kot Mehrath kasabasında dünyaya gelmiştir. ${ }^{2}$ İlerleyen yıllarda Lahor'a giderek hayatını burada devam ettirmiştir.

Zafer Ali Hân ilk eğitimini evde almış sonrasında 1888 yılında Vezîrabâd'taki Mission High School'da, 1890 yılında Patyâla'daki Mehindira Kaliciyet High School'da eğitim görmüştür. ${ }^{3}$ Buradan mezun olduktan sonra 1892 yılında Aligarh Üniversitesi (Mohammeden Anglo Oriental College)'ne giriş sınavını başarılı olarak burada eğitimine devam etmiştir. ${ }^{4}$ Aligarh Üniversitesi'ni başarıyla bitirmiş ve burada Allâme Şibli Numânî, Prof. Thomas Arnold, Seyyid Ahmed Han gibi Alt kitanın önde gelen ilmî, edebî ve siyasî şahsiyetlerden etkilenerek Aligarh'ın ilmî, edebî ve siyasî ortamından istifade etmiştir. 1857 yılında İngilizlerin yönetimi tamamen ele geçirmesinden sonra Müslümanlar özgürlük mücadelesine girmişler, kaybettikleri itibar ve özgürlüklerini yeniden kazanmaya çabalamışlardır.

XIX. yüzyıl, sömürge güçlerin hâkimiyetlerinin artmasıyla dünyadaki dengelerin değiştiği bir dönemdir. Bu yüzyılda etkisini gösteren milliyetçilik akımı çok uluslu devletlerin parçalanmasına sebep olmuştur. Alt kıtanın İngiliz sömürge güçlerinin hâkimiyeti altında bulunduğu dönemde Osmanlı Devleti de çöküşe geçmiştir. Kırım Savaşı, 93 Harbi, Trablusgarp Savaşı ve Balkan Savaşlarıyla sarsılan Osmanlı Devletine destek için Hint Müslümanları tarafından "Hindistan Hilafet Hareketi” adlı oluşum ortaya çıkmıştır. Bu vesileyle Avrupa devletlerinin Müslümanlara yaptığı saldırılar karşısında birleşmişlerdir. Alt kıtanın çeşitli bölgelerinde merkezler kurarak Hilafet Hareketi kapsamında çalışmalar yapmışlardır. Tek bağımsız kalan ve Müslümanların hâmisi olarak gördükleri Osmanlı Devleti’ni ayakta tutmak için "Zemindar", "El-Hilâl”, "Comrade", “El-Vekil” gibi gazeteler aracılığıyla Türklere desteklerini sürdürmüşlerdir. 5

1 Asıl adı Hudadad Han'dır, tarihte geçen adı ise Zafer Ali Hân'dır.

2 Zâhid Ali Han (Düzenleyen, Tahkik Eden), Külliyat-ı Mevlânâ Zafer Ali Hân, Alfaysal Nâşirân-u-Tâcirâni Kütüb Gazni Street Urdu Bazaar Lahore, Lahor, Nisan 2007, s.i.

3 Raja Esed Ali Hân, Baba-i Sahâfat Mevlânâ Zafer Ali Hân Ayk Taâruf, Ganj-1 Şeker Printers, Lahor, 2018 , s. 15.

4 Muhammed Ali Çarâğ, Akâbirîn-i Tahrîk-i Pakistan, Sang-i Mîl Publications, Lahor 2003, s. 416.

5 Arzu Çiftsüren, 93 Harbinden Sonra Hindistan-Pakistan Alt kıtasında Urduca ve Farsça Şiirde Türkiye ve Türkler, Yayınlanmamış Doktora Tezi, İstanbul 2013, s. v-vi. 
İngilizlerin, Hint alt kıtasında varlıklarını arttırmasının ardından 1857 yılında Hint halkı bağımsızlık için mücadele etmeye başlamış ve bu doğrultuda aynı yıl "Büyük Sipahi Ayaklanması" yaşanmış ve bu ayaklanma İngilizler tarafından şiddet kullanarak bastırılmıştır. Sonrasında İngilizler hâkimiyeti tamamen ele geçirmiş ve Hint halkı, özellikle de Müslümanlar, üzerindeki baskı daha da arttırmış, çeşitli zulüm yollarına gidilmiştir. Üstünde güneşin batmadığı korku duyulan bir sömürü düzenini kuran İngilizlere karşı, Hint Müslümanlarından ilk olarak, sesini basın aracılığıyla dile getiren ve Hint halkına mücadele ruhunu kazandıran Zafer Ali Hân'a bu sebeplerden "Hint basınının babası" denmiştir. Kanpûr şehri, 1857 Sipahi ayaklanmasının başladığı ilk yerdir. Kanpûr şehrinde yol genişletme çalışmalarında, İngilizlerin 1913 Temmuz ayında Kanpûr Camii avlusundaki abdesthane kısmını yıkarak yola katması sonucu İngilizler ve Hintli Müslümanlar arasında şiddetli çatışmalar meydana gelmiştir. Bu olay İngilizler karşısında muhalefetin güçlenmesine sebep olmuştur. ${ }^{6}$ Bütün bu süreci Zemindâr gazetesi cesurca dile getirmiş ve milletin tercümanı olmuştur. Zemindâr gazetesinin bu tutumu karşısında İngilizler Zafer Ali Hân'1 10.000 rupi kefalete mahkûm ederek gazetesinin basımını durdurmuştur. İleride Pakistan'ın kuruluşuna kadar bu kapatma faaliyetleri devam edecektir. ${ }^{7}$ Kanpûr olayının altında yatan asıl sebebini dönemin eyalet valisi Meston şöyle açıklamaktadır:

“Türkiye'nin sılkıntıları ve onun düşmanlarının işlediği insanî suçlar, Ingiltere'nin bütün bunlara kayıtsızlığ veya desteklendiğinin sayılması, genç Müslümanlara aradıkları bahaneyi verdi ve mitinglerde, camilerde veya fütursuz gazete makaleleri ile tahriklerde bulundular. ${ }^{8}$

Siyasî alanda birçok oluşumun içinde çeşitli görevlerde yer alan Zafer Ali Hân, hocası Allâme Şiblî Numanî'nin tavsiyesiyle Bombay ${ }^{9}$ şehrinde Navvâb Muhsin'ül-Mülk'ün özel kalemi olarak hizmette bulunmuş ve İçişleri Bakan Yardımcılığı'na kadar yükselmiştir. ${ }^{10}$ Bu sırada edebî faaliyetlerini de sürdüren Zafer Ali Hân, birçok felsefi metinleri İngilizceden Urducaya tercüme etmiş ve Dr. John William Draper’ın "History of the Conflict Between Religion and Sceince" adlı kitabını "Ma'reke-i Mezheb ve Sains" adıyla İngilizceden Arapçaya tercüme etmiştir. ${ }^{11}$ Zafer Ali Hân bu kitabın bir nüshasını Halife Abdülmecid Efendi’ye hediye etmiştir. ${ }^{12}$

6 Azmi Özcan, "KANPÛR", TDV

8 Azmi Özcan, Pan-İslamizm (Osmanlı Devleti Hindistan Müslümanları ve İngiltere 1877-1924), Ankara 1997, s. 210.

9 Hindistan'ın önemli şehirlerinden Bombay şehrinin adı 1995'te Mumbai olarak değiştirilmiştir.

10 Muhtâr Ahmad Makkî, a.g.e., s.327.

11 Muhammed Ali Çarâğ, a.g.e., s. 416.

12 Zafer Ali Hân tarafından Halife Abdülmecid Efendi’ye tercümesinin bir nüshası ithaf edilmiştir. Eser, 19. Yüzyı1 saray cildi (Yıldız cildi) özelliklerini taşımaktadır. 
“Dekken Review” gazetesini çıkaran Zafer Ali, alt kıtanın ilk gazetecileri arasındaki yerini almıştır. Bu gazetede yazıları yayımlanan isimler arasında Mevlevi Aziz Mirza, Allâme Şiblî, Mevlânâ Taba Tabaî, Azîz Lakhnovî ve Abdülhak gibi saygın edebî, şair ve öncü şahsiyetler de bulunmaktaydı. Dekken Review'in popülaritesi zamanla onun saray entrikalarına kurban gitmesine neden olmuştur. İngiliz hükümetinden maaş alan Babür saltanatının veliahtı Bahadır Mîr Osman Ali Han'ın İngiliz aleyhine olan yazısını Zafer Ali Hân kendi gazetesinde yayınlatmakla suçlanmıştır. ${ }^{13}$ Bu sebeple Haydarâbâd'1 zorunlu olarak terk edip büyüdüğü yer olan Keremâbâd'a gitmiştir. Babası gazetenin her türlü yayımcılık ve idare işlerini Zafer Ali Hân'a emanet etmiş, 6 Aralık 1909 tarihinde babasının vefatı üzerine de babasının kurduğu "Zemindâr" gazetesinin başına geçerek bu gazeteyi Müslüman toplumların sesi haline getirmiştir. Hint alt kıtasının ilk Urduca gazetesi Zemindâr, bölgede yaşayan Müslüman ırklar tarafından öyle kabul görmüştür ki sınır bölgesinde yaşayan Peştu kavmine mensup ve okuma yazması olmayan biri bile 2 rupi vererek bu gazeteyi almayı kendine vazife bilmiştir. ${ }^{14}$ Pencap bölgesinde kısa sürede geniş kitleye hitap eden haftalık gazete, zamanla adeta siyaseti etkiler hale gelmiştir. Zafer Ali Hân, bu gazetenin yanında "Pencap Rewiev" adlı gazeteyi de 1910 yılının ortalarında çıkarmaya başlamıştır. İlerleyen süreçte gazetelerinin neşrini Lahor'a taşımıştır. ${ }^{15}$

Zafer Ali Hân, gazetelerde İngiliz Hükümeti’ni eleştiren yazılar yazdığından, İngiliz Hindistan Hükümeti tarafından hoş görülmemiş ve bir şekilde sesi bastırılmaya çalış1lmıştır. Bu sebeple Zemindâr gazetesinin yayın yapma izni iptal edilmiş ve tekrar yayın hayatına dönmesi için 300.000 Rupi kefalet ödenmesi istenmiştir. Bu olay üzerine Zafer Ali Hân, İngiltere'ye giderek "Hindistan Basın Hareketi” (India Press Act) aleyhine yazılar kaleme almış, böylece İngiliz kamuoyunu dikkatini çekmeye çalışmış ve parlamento üyeleri ile buluşarak kendi görüşlerini açıklamıştır. Bu esnada onların hayat tarzını yakından inceleme firsatı bulan Zafer Ali Hân, Hindistan'a dönüşünde kendi gazetesi Zemindâr'da aşağıdaki eleştirel mısralarla başlayan uzun bir mazmun yayımlayarak gözlemlerini ve düşüncelerini ifade etmiştir:

"Londra'nın hediyesi dört şeydir.

İçki, hınzır, günlük gazete ve kadın.”

13 Muhtâr Ahmad Makkî, Tahrîk Âzâdî ke Musalmân Mucâhidîn ki Dâstân Tahrîk Âzâdî ke Numâyinda Muslim Mucâhidîn, Çûhdrî Gûlâm Rasûl and Sons Publishers, Lahor, 2005, s.327-328.

14 Raja Esed Ali Hân, a.g.e., s. 70.

15 Muhammed Ali Çarâğ, a.g.e., s. 419. 
Şeklinde başlayan şiirinin bu ilk mısraından da anlaşılacağı üzere şiirde, İngilizleri çok sert bir dille eleştirmiştir. Bunun üzerine İngiliz Hükümeti gazeteyi kapatmış ve 10.000 Rupi kefalet ücreti ile cezalandırmıştır. Halk bu yaşananlar karşısında büyük çapta gösteriler düzenleyerek İngiliz yönetimi tarafindan alınan bu kararı protesto etmiştir. Kefalet ücreti halk tarafından toplanıp İngilizlere iletilmiştir. ${ }^{16}$

Zafer Ali Hân'ın Zemindâr gazetesi yanında bu dönemde Muhammed Ali ve Şevket Ali kardeşler tarafından çıkarılan "The Comrade", Ebu'l-Kelâm Âzâd'ın "El-Hilal” gibi gazeteler, bir mücadele ve İslam birliğinin tekrar inşası için önemli bir araç olmuştur.

İtalyanlar, 1911 yılında Afrika'nın kuzey sahillerindeki Müslümanlara saldırdıklarında Zafer Ali Hân, İtalyanların bu saldırısını yeni bir Haçlı savaşııın başlangıcı olarak nitelemiştir. Trablusgarp ve Balkan Savaşları, Zafer Ali Hân'ın şiirlerinde yoğun bir şekilde akis bulmuştur. Zafer Ali Hân, Trablusgarp Savaşı'ndan itibaren Hilâl ile Haçın muharebesi olarak nitelediği pek çok şiir yazmıştır. Hintli Müslümanlar, Türklere karşı yapılan bu Haçlı savaşında ayağa kalkmıştır. Zafer Ali, onların hissiyatlarının Güney Hindistan'daki tercümanı olmuştur. Trablusgarp savaşı sonrasında Türkler üzerine Balkan Devletleri savaş açarak Türkleri ve Müslümanları Avrupa kıtasından silmek istemişlerdir. Bu savaş Avrupa devletlerinin Balkan devletlerini Osmanlı ile savaşa girmesi için teşvik etmeleriyle ortaya çıkmıştır. İngiltere de teşvik eden bu devletlerin başında gelmiştir. Hintli Müslümanlar, bu sayede açık bir şekilde kendilerini yöneten gücün gerçek yüzünü görmüş ve bu durum Hint Müslümanlarında birleşme ve bağımsızlık duyguları uyanmasına vesile olmuştur. ${ }^{17}$ Aynı zamanda bu süreçte alt kıtada yardımlar toplanmış ve Zafer Ali Hân Hint alt kıtasındaki Türklere yardım toplayan öncü isimlerden olmuştur. ${ }^{18}$ Gazete ve sokaklara asılan afişler ile ve diğer tüm yardım faaliyetleri sonucunda Mayıs 1913 yılında Osmanlı Devleti için Hindistan'da toplanan yardım miktarı tüm dünyadan toplanan yardımın yarısından fazlasını oluşturmuştur. ${ }^{19}$ Zafer Ali Hân ve Trablusgarp Balkan savaşları üzerine İngilizleri suçlayan yazılar kaleme almış ve "Zemindâr Vakfı" adı altında kısa bir zaman içinde, yokluklar içinde savaş mücadelesini veren Türkler için, 600.000 rupi toplayıp Türkiye'ye yollamıştır. ${ }^{20}$ Bu yardım faaliyeti

16 Muhtâr Ahmad Makkî, a.g.e., s.328.

17 Nazîr Hasneyn Zaydî, Mevlânâ Zafer Ali Hân Ahvâl-u Âsâr, Maclis-i Tarakki-yi Adab, Lahor, 1986, s.92-93.

18 Nand Kishore Vikram, Musawwar Tazkerey, Sanjiu Ofset Printers, Delhi, 2012, s. 453.

19 Azmi Özcan, Pan-İslamizm (Osmanlı Devleti Hindistan Müslümanları ve İngiltere 1877-1924), Ankara 1997, s. 192-193.

20 Muhtâr Ahmad Makkî, a.g.e., s.328. 
sırasında Zafer Ali Hân’ın iki gazetesinin toplam günlük baskıs1 30.000 kadardı. Zemindâr gazetesi 1910 yılında mahalli ölçekte bir gazete iken Zafer Ali Hân ile birlikte millî şuurun tezahürü olan bir gazete haline gelmiş ve günlük baskısı 20.000 civarına ulaşmıştır. ${ }^{21}$ Balkan Savaşına özel olarak bir baskı Zemindâr gazetesi tarafından çıkarılmıştır. Balkan Savaşlarında Hintli Müslümanlar Osmanlı Ordusu'nda savaşa girmişler ve sağlık heyetleri göndermiştir. Zafer Ali Hân ve Muhammed Ali “Rumeli Muhacirlerine Yardım Cemiyeti”' adı altında Balkan Savaşları'nda Osmanlı’ya sı̆̆ınan muhacirlere yardım etmek için bir yardım kuruluşu tesis etmişlerdir. Hindistan Hilafet Komitesi tarafından Osmanlı’ya gönderilen iki önemli isim olan Zafer Ali ve Dr. Ensarî, Mısırlı Fuat Bey ile birlikte Ankara, Konya, Adana gibi Anadolu şehirlerini gezmiş ve Balkan göçmenleri için Adana'da başlangıçta 200 ev yapmaya karar vermiş ${ }^{22}$ ve Hint Müslümanlarından yardımlar toplanıp İstanbul'a bu amaçla gönderilmiştir. ${ }^{23}$

Zafer Ali'nin Türklere karşı bu tutumu tüm Müslümanlar tarafından takdir edilmiş, onun Türkiye’ye gelişi ve sonrasında Hindistan’a dönüşü sırasında onu alt kıta Müslümanları coşkuyla karşılamıştır. Osmanlı Sultanı Mehmet Reşat ve diğer devlet adamları tarafından da Zafer Ali Hân ağırlanmıştır. Türkiye' den Hindistan'a dönüşünde tutuklanma ihtimalinden dolayı, Delhi'den Lahor'a ulaştığında kendisini 100.000 civarında Hintli Müslüman karşılamıştır. Zafer Ali Hân'a Müslümanlar tarafından bu derece sayg1 duyulması, sahiplenilmesi İslam birliği için yaptığı çalışmaları sebebiyle olmuştur. İslam birliğinin oluşumu ve dayanışması için medya ve edebiyatı bir araç olarak kullanmıştır. Lahor'da kendisi için toplananlara hitaben Osmanlı Halifesinden selam getiren Zafer Ali Hân, Sultan'ın Delhi'deki Şâhî Câmia Mescid² ${ }^{24}$ için halı hediyesini, Medine'de yapılacak olan İslamî eğitim alınabilecek bir üniversiteyi pek yakında açacaklarının ve Dar'ulfünûn-i Osmanî'de Urdu Dilinin öğretileceğinin mevcut hükümet tarafından karar verildiğinin müjdesini vermiştir. ${ }^{25}$ Osmanlı Halifesi ve Türk Milleti’nin bekası için dualar edilmiştir. ${ }^{26}$ Nazîr Hasneyn Zaydî’nin Mevlânâ Zafer Ali Hân “Ahvâl-u

21 Azmi Özcan, a.g.e., s.179.

22 Hasan Taner Kerimoğlu, “Trablusgarp Ve Balkan Savaşlarında Hint Müslümanlarının Osmanlı Devleti’ne Yaptıkları Yardımlar”, Türk Dünyası İncelemeleri Dergisi / Journal of Turkish World Studies, XII/2 (Kış 2012), s. 162.

23 Azmi Özcan, a.g.e., s.199.

24 Türkçede Cuma Mescidi denilmektedir.

25 Nitekim çok kısa bir süre sonra 1915 yılında İstanbul Üniversitesi'nde Urdu dili eğitimi Abdülcabbar Hayri tarafindan verilmeye başlanmıştır.

26 S.M. Tevfik, Sebîlürreşâd (Dînî, İlmî, Edebî, Siyâsî Haftalık Mecmûa-i İslâmiyye), Cilt 11 Sayı 261-286, Proje Yürütücüsü M. Ertuğrul Düzdağ, Bağcılar Belediyesi 2007, s. 27-28. 
Âsâr" adlı çalışmasında, Pencap Valisi Michael O'Dwyer (1912-1919)'den naklettiği üzere Zafer Ali Hân'ın tutuklanma sebebini, Hindistan'a dönüşü sırasında Türkiye'den Şâhî Câmia Mescid için halı getirmesi, Türkiye'ye gönderilen sağlık heyetindeki iki doktorla gizli gizli görüşme yapması ve Londra'ya gittiği sırada Hindistan Basın Hareketi (India Press Act) aleyhine konuşmalar yapması ile Londra'dan dönüşünde Türkiye'ye uğraması olarak belirtmiştir. ${ }^{27}$ Yukarıda da belirttiğimiz gibi, İngilizler, Hint alt kıtasındaki Müslümanların giderek İslam çatısı altında birleştiklerini görünce önde gelen ve ve topluma yön veren kişileri tutuklamaya başlamıştır. Zafer Ali, Ebu'l-Kelâm Âzâd, Hasret Mohanî, Muhammed Ali kardeşler de bu tutuklananlar arasında yer almıştır. $^{28}$ Zafer Ali Han da I. Dünya Savaşı başlarken çeşitli suçlamalarla İngilizler tarafından tutuklanmış ve Pencap Valisi Michael O'Dwyer döneminde, Zafer Ali Hân beş y1l boyunca zorluklarla dolu hapis hayatı geçirmiştir. ${ }^{29}$ İnsanların bulunduğu coğrafyada onu önder bir kişi olarak kabullenilip peşinden gitmelerinin alt yapısında onun entelektüel birikimi, İslâm birliği düşüncesi ve özgürlük mücadelesini de dinî ve millî duygularla yapıyor olması gibi sebepler bulunmaktadır. İngiliz esareti altında kalmış Güney Asya Müslümanlarında millî bir şuur oluşturup, İslam birliği ile esaretten kurtulmaları için mücadele vermiştir.

Mevlânâ Zafer Ali Hân, etkili bir hâtip ve özgürlük hareketinin öncü liderlerinden olmasının yanı sıra şairliği ile de Urdu edebiyatında yüksek bir makama sahiptir. Urduca düzyazı ve şiirde pek çok eseri bulunmaktadır. Aynı zamanda Mevlânâ Hâli'den devraldığı naat geleneğinin dönemindeki bir temsilcisi de olmuştur. ${ }^{30}$ Zafer Ali, etrafındaki olaylar hakkında kolaylıkla yüzlerce beyit yazabilen bir hünere sahipti. Döneminde yaşanan dünyadaki ve özelde İslam medeniyeti ile alakalı siyasî, dinî ve toplumun sslahı ile alakalı yazılar kaleme almış şiirler yazmıştır. Nitekim İkbal'in, Zafer Ali Hân hakkındaki şu sözleri alt kıtadaki önemini gösterir:

"Bana göre Mevlânâ Zafer Ali Hân, muhteşem bir kalbe ve düşünceye sahip bir kişiliktir. Onun İslam milleti için yaptı̆̆ mücadeleler takdire şayandır. Kaleminin gönüllere sihirli dokunuşu büyük büyük mücahitlerin kilıçlarından daha aşağl değildir. Böylece bütün Hint alt kıtası ondan etkilenmiştir. Zafer Ali Hân, özellikle Pencap bölgesindeki Müslümanların

27 Nazîr Hasneyn Zaydî, a.g.e., s.108.

28 Mohammed Sadiq, Çeviren Funda Keskin Ata, Türk Devrimi ve Hindistan Özgürlük Hareketi, Türk Tarih Kurumu, Ankara, 2018, s. 57-58.

29 Nand Kishore Vikram, Musawwar Tazkerey, Sanjiu Ofset Printers, Delhi, 2012, s.453-454.

30 Recep DURGUN, “Ahmet Rıza Han Barelvi’nin Hadâik-i Bahşiş Adlı Eserinde Hz. Peygamber ile İlgili Benzetmeler”, Selçuk Ün. Sos. Bil. Ens. Der. 2017; (37): 122-133 - Urdu Dili ve Edebiyatı / Araştırma, Konya, 2017, s. 125. 
kalbinde büyük bir yere sahiptir. Çünkü dinî, siyasî, edebî yönden Pencap bölgesi için büyük hizmetleri yapmaya muvaffak olmuştur. "’1

İngilizler, diğer gazeteciler gibi, Zafer Ali Han'1 da hapse girmeden önce Keremâbâd'ta beş yıl boyunca göz hapsinde tutmuşlardır. Aralarda bu göz hapsini gevşettikleri sırada Zafer Ali Hân, Lahor'a gidip gelerek "Sitara-i Subah" isimli dergi vasıtasıyla sesini daha geniş alanda duyurabilmiştir. ${ }^{32}$

İngiliz Hindistan Hükümeti yukarıda zikrettiğimiz sebepleri öne sürerek Zafer Ali Hân'1 tutuklamıştır. Çeşitli aralıklarla olmak üzere 1914-1924 yılları arasında 5 yıl hapis yatmıştır. Zafer Ali, 1930 yılında Gandhi’nin başlattı̆̆g sivil itaatsizlik hareketine destek vermiş ve İngilizler tarafından halkı İngilizlere karşı kışkırtan konuşmalar yapmasıyla suçlanarak tekrardan tutuklanmıştır. ${ }^{33}$ Hapiste kaldığı sürece dinî, siyasî, İslam tarihi, toplumsal, kendi zihin ve kalp dünyasındaki düşünceleri içeren 148 tane şiir kaleme almıştır. Şiir külliyatında yer alan "Habsiyât" kısmı bu şiirlerden oluşmaktadır. Hapishanede olduğu süreçte diş dünyayla ilişiği maddi olarak kesilmiş olsa da Zafer Ali Hân'ın ruhu, fikirleri, vicdanî ve millî duyguları hür kalmıştır. Bu sebeple hapishanede de İslam ve ülke meseleleri üzerine gece gündüz düşünmüş ve hissiyatını konuşmalar yaparak özgürce dile getiremese de duygularını kalemiyle kâğıda işlemeyi sürdürmüştür. Sahîvâl hapishanesinde kaldığı günlerde şiirlerini dışarı çıkartmanın bir yolunu bularak Zemindâr gazetesinde "Müslim" mahlası ile yayımlatmaya devam etmiştir. ${ }^{34}$

Mevlânâ Zafer Ali’ye hapishane günleri ile alakalı yıllar sonra, mevcut dönem ile kendisinin hapishaneye girdiği dönemdekiler arasındaki fark sorulmuş ve Zafer Ali, yer ve gökyüzü kadar fark olduğunu söylemiş ve devam etmiştir:

"Hapishanelerin kapı ve duvarlarını bile insanın görmesi, iliklerine kadar titretmesine yetmiştir. Hilâfet Hareketi mensuplarının toplu olarak tutuklanması hapishanelerin bu ürkütücü havasını silmiş ve insanların kalplerinden İngiliz korkusu çıkmıştır. O zamanlar Ingilizler tarafindan, siyasî tutuklular, ahlak suçları tutuklularından daha çok tehlikeli oldukları addedilmiştir. Ĕger biz hala dar ve karanlık hücrelerden konuşuyorsak, bu durumun aynen tasviridir. Insan hapishanelerin korkunçluğunda delirmektedir. Bir insan tutuklandiğg anda sivil özgürlügünden mahrum olmaktadır. Işste bu hapistir. Tutuklu artık insan olarak kalmaktan çıkar. Hapishane yönetimi hayvanlardan daha kötü bir şekilde davranmaktadır. Hilafet hareketi ve sivil itaatsizlik hareketi hapishanelerin yapısını değiştirmiş ve korkuları

31 Muhammed Ali Çarâğ, A.g.e., s. 423.

32 Gulâm Hüseyin Zülfikâr, Mevlânâ Zafer Ali Hân, Sang-i Meel Publications, Lahor, 1993, s. 186.

33 Muhtâr Ahmad Makkî, a.g.e., s.328-329.

34 Gulâm Hüseyin Zülfikâr, a.g.e., s. 194. 
silmiştir. Hapise girilmekten gurur duyulmaya başlanmıştır. Bizden önce yerli tutukluların dünyadaki makamı dikkate bile alınmazdı. Sadece Avrupalılar için ayrıcalık vardı. Onlar ne gardiyanın hükmünde olurdu ve ne de onlar diğer tutukluların yanına konurdu. Hırsizlık yapsa dahi ekmek ve tereyağı almaya hakları vardı. Onların koğuş hayatı için ayrı bir düzen kurulmuştu" 35

Zafer Ali, hapishane koşullarını yukarıdaki sözlerinin yanında, 1930 yılının sonlarında bir aylığına Lahor merkez hapishanesine mahkûm edildiğinde, 25 Aralık 1930 tarihinde, "Lahor Merkez Hapishanesi”" adıyla yazdı̆̆ı şiirde de anlatmıştır. Bu şiirin yazıldığ1 dönemde, hapishaneleri siyasî tutuklular ve özgürlük isteyen gençlerle dolu bulunmaktaydı. Şiirde hapishane şartlarını şu dizelerle anlatmaktadır:

Bugün onların hatası biraz kara olmakt1. ${ }^{36}$

Hapis gardiyanları onların kanını içmekte.

Bazen öğütücü makinesinin ${ }^{37}$ meşakkati, bazen değirmen çevirme ${ }^{38}$ azab1, Bunlarla o çaresizlerin elleri su toplamakta.

İngilizler işkence makineleri için,

Kan ve etten parçalarına dönüştürmüştür onları! $!^{39}$

Beyaz tutuklular da var hırsızlıktan ancak, onlar için

Yöneticiler hapishaneyi gül bahçesine çevirmekte.

Biz hiçbir konuda geri değiliz ancak,

Ne yapalım ki onlar ak, biz kara.

Renk ayrımının üzerine kurulmuş Frenk kanunu,

İşte böyle modern medeniyetin iflası ortaya çıkmakta.

Meclisin tüm vekilleri niçin susmakta?

Çünkü onlar bu zulmün ortaklarıdır.

Bir battaniye sahibinin ümmetinin bir battaniyesi bile yok, Şapkalılara kıymetli ipek şallar peşkeş çekilmekte. ${ }^{40}$

35 Shoraş Kâşmirî, Kayd-ı Freng Mevlânâ Zafer Ali Hân, Mevlânâ Zafer Ali Hân Trust, Lahor, 2011, s. 46.

36 Biraz kara sözünden Afrikalı değil Hintli olduğu anlaşılmaktadır.

37 Öğ̈tücü makinesi, bölgesel bitki olan sarsû bitkisinin tohumlarından yağ üretmeye yaramaktaydı ve bu aleti kullanmak çok zahmet vericiydi.

38 Buğdayı öğütüp un haline getirme makinesidir.

39 Hint yerliler kastedilmiştir.

40 Görevde yükselen ve İngiliz hükümeti tarafından ödüllendirilmek istenen İngilizlere verilen kaftan gibi kıymetli bir şal. 
Büyük günde hürriyet isteyenlere şu hediye düştü:

Mücadelede hayatlarını feda ettiler.

Uhud $^{41}$ geleneği zindanda tekrar hayat buldu.

Allah yolunda onların dişleri kırıldı.

$\mathrm{Bu}$ şekilde İslam ehli yakarıp durursa fışkıracaktır!

Gökyüzündeki tüm evlerin oluklarından rahmet.

Söyle bunu sarhoşluğa kapılanların hepsine,

Zenginlikten çok çabuk sarhoş olup kaçacaksın. ${ }^{42}$

Mevlânâ Zafer Ali Hân, İngiliz hapishanelerinin ağır şartlarını içeren diğer bir şiirini 1930 yılında yazmıștır. Ancak bu şiirin yayımlanması İngilizler tarafından yasaklanmıştır.

İngiliz hapsi ve hayat hapsi arasında fark yoktur,

Ölmeden önce insan bu hapisten nasıl çıkar.

Feryâdı kontrol etmek ey dostum, İngiliz zulmüne cevaptır, ${ }^{43}$

Sabır gösterme iddiasındaysan, niçin acıdan titreyesin?

Günahsızların kanının lekesi İngilizlerin elbiselerindedir, İnkılap perdesinde kader niçin yenilik getirmesin. ${ }^{44}$

Yukarıda da belirttiğimiz gibi halkının özgürlük mücadelesi yolunda ve Türklerin milli mücadelesine verdiği destek ile beş yılı aşkın hapis yatmış olsa da haklı davasından vazgeçmemiş ve ömrünü mücadeleyle geçirmiştir. Şüphesiz alt kıta basın tarihinde, özgürlük mücadelesinde ve Türk milli mücadelesindeki rolü ile hem alt kıta hem de Türkler için unutulmayacak öncü şahıslardan biridir.

Hakem Değerlendirmesi: Dış bağımsız.

Çıkar Çatışması: Yazar çıkar çatışması bildirmemiştir.

Finansal Destek: Yazar bu çalışma için finansal destek almadığını beyan etmiştir.

Peer-review: Externally peer-reviewed.

Conflict of Interest: The author has no conflict of interest to declare.

Grant Support: The author declared that this study has received no financial support.

41 Hz. Muhammed (sav)' in Uhud savaşında dişlerinin kırılmasına atıfta bulunmaktadır.

42 Zahid Ali Hân (Düzenleyen ve Tahkik Eden), Külliyat-ı Mevlânâ Zafer Ali Hân (Habsiyât), Al-Faysal Naşirânü Tâcirân-i Kütüb, Lahor, 2007, s.133-134.

43 Sivil itaatsizlik hareketine atıf yapılmıştır. Zafer Ali bu harekete katılmıştır.

44 Shoraş Kâşmirî, a.g.e., s. 70. 


\section{Kaynakça/References}

Çarâg, Muhammed Ali, Akâbirîn-i Tahrîk-i Pakistan, Sang-i Mîl Publications, Lahor 2003.

Çiftsüren, Arzu, 93 Harbinden Sonra Hindistan-Pakistan Alt kıtasında Urduca ve Farsça Şiirde Türkiye ve Türkler, Yayınlanmamış Doktora Tezi, İstanbul 2013

Durgun, Recep, “Ahmet Rıza Han Barelvi'nin Hadâik-i Bahşiş Adlı Eserinde Hz. Peygamber ile İlgili Benzetmeler”, Selçuk Ün. Sos. Bil. Ens. Der. 2017; (37): 122-133 - Urdu Dili ve Edebiyatı / Araştırma. Gulâm Hüseyin Zülfikâr, Mevlânâ Zafer Ali Hân, Sang-i Meel Publications, Lahor, 1993.

Hân, Raja Esed Ali, Baba-i Sahâfat Mevlânâ Zafer Ali Hân Ayk Taâruf, Ganj-1 Şeker Printers, Lahor, 2018. Hân, Zahid Ali (Düzenleyen ve Tahkik Eden), Külliyat-ı Mevlânâ Zafer Ali Hân (Habsiyât), Al-Faysal Naşirânü Tâcirân-i Kütüb, Lahor, 2007.

Hân, Zâhid Ali (Düzenleyen, Tahkik Eden), Külliyat-ı Mevlânâ Zafer Ali Hân, Alfaysal Nâş̧irân-u-Tâcirâni Kütüb Gazni Street Urdu Bazaar Lahore, Lahor, Nisan 2007.

Kâş̧mirî, Shoraş, Kayd-ı Freng Mevlânâ Zafer Ali Hân, Mevlânâ Zafer Ali Hân Trust, Lahor, 2011.

Kerimoğlu, Hasan Taner, "Trablusgarp Ve Balkan Savaşlarında Hint Müslümanlarının Osmanlı Devleti'ne Yaptıkları Yardımlar”, Türk Dünyası İncelemeleri Dergisi / Journal of Turkish World Studies, XII/2 (Kış 2012).

Makkî, Muhtâr Ahmad, Tahrîk Âzâdî ke Musalmân Mucâhidîn ki Dâstân Tahrîk Âzâdî ke Numâyinda Muslim Mucâhidîn, Çûhdrî Gûlâm Rasûl and Sons Publishers, Lahor, 2005.

Mohammed Sadiq, Çeviren Funda Keskin Ata, Türk Devrimi ve Hindistan Özgürlük Hareketi, Türk Tarih Kurumu, Ankara, 2018.

Özcan, Azmi, “KANPÛR”, TDV İslâm Ansiklopedisi, https://islamansiklopedisi.org.tr/kanpur (09.11.2019). Özcan, Azmi, Pan-İslamizm (Osmanı Devleti Hindistan Müslümanları ve İngiltere 1877-1924), Ankara 1997.

Tevfik, S.M., Sebîlürreşâd (Dînî, ilmî, edebî, siyâsî haftalık mecmûa-i İslâmiyye), Cilt 11 Sayı 261-286, Proje Yürütücüsü M. Ertuğrul Düzdağ, Bağc1lar Belediyesi 2007.

Vikram, Nand Kishore, Musawwar Tazkerey, Sanjiu Ofset Printers, Delhi, 2012.

Zaydî, Nazîr Hasneyn, Mevlânâ Zafer Ali Hân Ahvâl-u Âsâr, Maclis-i Tarakki-yi Adab, Lahor, 1986. 